\title{
British Columbia Division
}

The THEME of the Annual Meeting of the Canadian Medical Association, held in Vancouver in June, was "Resuscitation" Papers from the Section of Anaesthesia mcluded

Dr M Minucx, from Manitoba "Cardiac Resuscitation",

DR H H MACARTNEY of Vancouver "Acute Respiratory Insufficiency"

Dr L C JENKINS of Vancouver "Chemical Treatment of Shock"

A film, entered by Dr $T$ McCaughey of Winnipeg, was shown, entitled "Emergency Resuscitation in Children"

A Panel with Dr Jone Chang, Dr L C Jenkans, and Dr H H Macartney discussed "Problems Associated with Prolonged Artificial Ventilation"

Dr Churchill-Davidson spoke to the B. C Thoracic Society, a sub-section of the C M A , on "Myasthenia Gravis"

Dr H C Churchill-Davidson gave a talk on Friday, June 26, to the B C Division, C A S The title of his paper was "The Clinical Use of Muscle Relaxants" He was entertained to dinner by the Executive and invited guests beforehand

Dr Eric Webb recently arrived in Lagos, Nigeria, where he will be taking up teaching duties associated with the Department of Anaesthesia, University of Lagos Medical School

Preparation is well under way for the forthcoming Western Biennial Meeting to be held in Vancouver, May 3 to 7, 1965

\section{Ontario Diviston}

The Annual Busıness Meetıng of the O M A Section on Anaesthesia was held on May 28, 1964, in the Alberta Room of the Royal York Hotel, Toronto, Ontario

The business meeting was preceded by a scientific session, at which timely subjects were delivered by $\operatorname{Dr} \mathrm{E}$ York, Toronto, and Dr Michael Diamond of Kitchener Dr Stanley Campbell was moderator for a panel discussion on cyclopropane and ether with Dr Barne Farrley, Toronto, Dr Wolfgang Spoerel, London, and Dr Stuart Vandewater of Kingston

Dr Frank Walker has returned from Great Britain, where he spent some tume on a McLaughlin Travelling Fellowship $\mathrm{He}$ is now associated with $\mathrm{Dr}$ W Spoerel in the Department of Anaesthesia, Victoria Hospital, London, Ontario

Dr John Cox, formerly of London, Ontano has taken up residence in Chicago, Illinos, where he is on the staff of the Department of Anaesthesiology of the Children's Memorial Hospital 
Dr Raymond Neill, formerly of Fort Willam, joined the Staff of the Kingston General Hospital and Queen's University in August, 1964.

Guest Speakers in the Department of Anaesthesiology, Queen's University, durIng 1963-64 were Dr Alastair J Gillies, Rochester, NY, Dr R O Heimbecker, Toronto, Dr John W Scott, Toronto, Dr Wolfgang \& Spoerel, London, Dr J B Sutherland, Montreal

The Annual Refresher Course for General Practitioners will be held at Queen's University on October 20,21, and 22, with Dr S M Campbell as guest lecturer

The Diploma in Anaesthesia of the University of Toionto was awarded for the first time at Convocation on June 17, 1964 The successful candidates were Dr Beverley Britt and Dr John Moran

Dr John Moran has joined the Staff of the Departmient of Anaesthesia of the Toronto General Hospital and the Department of Anaesthesia, University of Toronto

Dr John Jacobs has joined the Department of Anaesthesia of St Michael's Hospital, Toronto, and the Department of Anaesthesia, University of Toronto

Dr Shrley Fleming is contunuing for a third year as Piofessor and Head of the Department of Anaesthesia of the Lagos University Medical School Professor Fleming is on leave of absence from the University of Toronto Dr Wells Renwick of the Department of Anaesthesia of the Toronto East General Hospital has joined the Department in Lagos as Lecturer $\operatorname{Dr} R \mathbf{M}$ McCutcheon from Queen's University is in Lagos as Registrar, replacing $\operatorname{Dr} \mathbb{R} M$ Hooper of The University of Toronto, who has returned to the South Peel Hospital, Toronto Dr Earl Russell, who has spent the past two years at the University of Lagos, has returned to Kingston

The sixth Dr Harry Shields Lecture will be given in "The University of Toronto on Friday, November 13 The Lecturer for 1964 is Dr Leroy Vandam of Boston

\section{NOUvLlles DU QuéBEC}

Lors de l'assęmblée annuelle de la Société Canadiennle des Anesthésıstes, tenue à Montebello du 10 au 14 ma1 1964, le docteur Léon Longtın, F R C P(C), F A A A, C S PQ, a été élu président de la Société $S_{1}$ l'on considere le travail accompli par le docteur Longtın dans le domaine de l'anesthésie en général, et partıculièrement dans le milıeu canadıen-françaıs, on peut être assuré que, sous sa direction, la Société atteindra de nouveaux sommets Depuis un quart de siècle, par son exemple, son enseignement, sa participation à des comités, à des forums à des congrès, le docteur Longtın a formé un bon nombre de jeunes anesthésistes qui sont répandus dans la province et à l'étranger Nous lui souhartons le plus entier succès au cours de son mandat

Le docteur Longtin sera l'un des délégués officiels de la Société Canadienne 
des Anesthésıstes au IIIe Congrès Mondıal d'Anesthésıologı quu sèra tenu à Sao Paulo, Brésil, en septembre prochain

Le docteur André Crépeau sera bientôt de retour de Seattle, Washington, où, depus un an, $\mathbf{l}$ a travallé sous la durection du docteur Danıel C Moore Dès son arrivée, il commencera la pratıque de sa spécialité dans le service d'anesthésie de l'Hôtel-Dieu de Montréal

Durant la prochaine année académıque, plusieurs résıdents en anesthésie de l'Hôtel de Montréal poursuvvront leurs étudeš à l'étranger Les docteurs Yvon Gravel et Yvon Turmel seront résidents en anesthésie dans le service du docteur Weston Bruner, Jr, à Washıngton, D.C , le docteur Etiennette Lebel travallera sous la direction du docteur Gordon Robson, à l'hôpital Hammersmith, Londres, Angleterre, et le docteur Andrée Pinault, à Boston, Mass, sous la direction du docteur Henry $\mathrm{K}$ Beecher On ne sauratt trop insister sur l'importance de ces séjours à l'étranger Nous leur souhaitons bon succès, et nous espéions que cette année d'études leur apportera une expérience enrichissante dont ils feront bénéficier leurs confrères

Professor and Mrs Gordon Robson were guests of honour at a recent dinner at the Ritz-Carlton Hotel in Montreal Members of the Staff in Anaesthesia of McGill University and the University of Montreal and their wives joined to wish them contunued health and happiness and to express regrets on their departure from Canada In October, Professor Robson will take over his new duties as Professor of Anaesthetics at the University of London This appointment will be tenable at the Postgraduate Medical School in Hanmersmith He will direct an active clinical service and, in addition, will enjoy the benefits of expanded research facilities

Professor $\mathbb{R}$ G $B$ Gilbert acted as chairinan for the evening, and at his request, Professor Harold Griffith recalled the history of the establishment of the Wellcome Research Department of Anaesthesia at McGll University During the past nine years, Doctor Robson has established himself as a congenial and thoughtful adviser to the clinical departments of all McGill Teaching Hospitals In addition, he has trained a number of younger men in his research department at McGill Gordon Robson has also become widely known across Canada and the United States as a much appreciated guest lecturer His appreciative colleagues at McGll did their best to express their sentuments at this time, and to congratulate him on his well-deserved promotion to a senior post in the British Commonwealth

As a finale, Doctor Gilbert presented the guests of honour with an oll painting entitled "Winter in the Laurentians"

Doctor Gladys Ellison, with her usual efficiency, acted as charman of the Dinner Committee 